Leininger, T. D., K. O. BRitton and C. J. Chang (2001): Determining the role of bacterial leaf scorch, canker stain, and Botryosphaeria canker in hte dieback of plantation sycamores in the southeastern United States. In: Shade Tree Wilt Diseases - Proceedings from Wilt Diseases of Shade Trees: A National Conference AsH, C., ed. St. Paul, MN. 209-216.

Leininger, T. D., N. M. Schiff and K. Corbin (2004): Hoalodisca coagulata trasmits Xylella fastidiosa to sycamore. Phytopathology 94: S59.

LYNCH, M. and B. WALSH (1996): Genetics and Analysis of Quantitative Traits. Sunderland, MA: Sinauer Associates.

Merkle, S. and M. Cunningham (2011): Southern hardwood varietal forestry: a new approach to short-rotation woody crops for biomass energy. Journal of Forestry 109: $7-14$

NAmkoong, G., E. B. Snyder and R. W. Stonecypher (1966): Heritability and Gain Concepts for Evaluating Breeding Systems such as Seedling Orchards. Silvae Genetica 15: 76-84.

Newcombe, G., B. Stirling and H. D. Bradshaw JR. (2001): Abundant pathogenic variation in the new hybrid rust Melampsora x columbiana on hybrid poplar. Phytopathology 91: 981-985.

RANNEY, J. W., L. L. WRIGHT and P. A. LAYTON (1987): Hardwood energy crops: the technology of intensive culture. Journal of Forestry 85: 17-28.

Riemenschneider, D. E. et al. (2001): Poplar breeding and testing strategies in the north-central U.S.: Demonstration of potential yield and consideration of future needs. Forestry Chronicle 77: 245-254.

Rousseau, R. J. (1989): Genetic performance and earlyage selection within a ten-year old mid-west sycamore progeny test. In: $20^{\text {th }}$ Southern Forest Tree Improvement Conference, Charleston, SC. 294-301.

Shommake, L. J., M. A. Arnold and F. T. DAVIES JR. (2004): Provenance impacts transplant establishment and adventitious root regeneration of sycamore. Journal of
American Society of Horticulture Science (2004) 129: 360-367.

Simpson, A. J. et al. (2000): The genome sequence of the plant pathogen Xylella fastidiosa. The Xylella fastidiosa Consortium of the Organization for Nucleotide Sequencing and Analysis. Nature 406: 151-159.

STEINBECK, K. (1999): Thirty Years of Short-Rotation Hardwoods Research. In: Tenth Biennial Southern Silvicultural Research Conference - HAYwooD, J. D., ed. Shreveport, Louisiana: U.S. Department of Agriculture, Southern Research Station. 63-65.

SteinbeCK, K., R. G. MCAlpine and J. T. MAY (1972): Short rotation culture of sycamore: a status report. Journal of Forestry 70: 210-213.

TAYLOR, F. W. (1969): Variation of wood properties in sycamore-Laboratory MSFPU, ed.: Mississippi State Forest Products Utilization Laboratory. 18.

TuskAN, G. A. (1998): Short-rotation woody crop supply systems in the United States: whay do we know and what do we need to know? Biomass and Bioenergy 14: 307-315.

Webb, C. D., R. P. Belanger and R. G. Mcalpine (1973): Family differnces in early growth and wood specific gravity of American sycamore (Platanus occidentalis L.). In: Proceedings of the $12^{\text {th }}$ Southern Forest Tree Improvement Conference, Baton Rouge, LA. 213-227.

Wells, J. M., B. C. RAJU, H.-Y. Hung, W. G. WeisburG, L. Mandelco-Paul and D. J. Brenner (1987): Xylella fastidiosa gen. nov., sp. nov: Gram-Negative, Xylem-Limited, Fastidious Plant Bacteria Related to Xanthomonas spp. International Journal of Systematic Bacteriology 37: 136-143.

WeLls, O. O. and J. R. Toliver (1987): Geographic variation in sycamore (Platanus occidentalis L.). Silvae Genetica 36: 154-159.

WitTMER, R. F. and M. J. IMmel (1976): A comparison of five tree species for intensive fiber production. Forest Ecology and Management 1: 249-254.

\title{
Performance Evaluation of Shrub Willow Clones of North America and Yugoslavia Origins in Jilin, China
}

\author{
By Q. F. MeNG ${ }^{1), 3)}$, W. T. GAO ${ }^{1)}$, J.Y PANG ${ }^{1)}$ and Y. H. WeNG ${ }^{2,3)}$
}

(Received $1^{\text {st }}$ Juni 2012)

\begin{abstract}
Demand for planting elite shrub willows as a resource for industrial use such as bioenergy and pulp has been increasing in Jilin province in northeast China. Toward

\footnotetext{
1) College of Forestry, Beihua University, 3999 Huashan Rd, Jilin City, 132013.

$\left.{ }^{2}\right)$ Tree Improvement Office, New Brunswick Department of Natural Resources, 3732 Route 102, Island View, New Brunswick E3E 1G3.

3) Corresponding authors: qingfanmeng@sina.com and Yuhui.weng@@gnb.ca
}

this end, 12 elite willow clones, representing various species and origins, were imported from New York, USA, and planted at Lushui River, Jilin province. Two indigenous species were included in the test as the controls for comparison. This study was an evaluation of their performance in adaptation, growth potential, and wood traits after one rotation (three growing seasons). Results indicated that (1) all clones, but one, showed a parallel phenology to the control, had excellent survival (>86\%) and displayed good frost resistance; (2) compared to the control, most imported clones were comparable in main stem growth (height and diameter), but developed more 
stems and main roots; and (3) most imported clones had similar lignin, but higher cellulose content relative to the control. These results imply that some of the imported clones should be considered for further evaluation as good sources for both bioenergy and pulping. Based on cluster analysis, six clones were recommended for the upcoming scale-up site-clone trials for yield evaluation.

Key words: adaptation, bioenergy, pulping, Salix, shrub willow, tree improvement.

\section{Introduction}

Growing concerns over global $\mathrm{CO}_{2}$ emissions from fossil fuel utilization have created the desire and urgency of developing biomass feedstock options for bioenergy. Spurred by their remarkable growth rate, cultivation of willow shrubs is an attractive option. Willow shrubs can not only sequester carbon from atmospheric $\mathrm{CO}_{2}$ but can also be used as an effective carbon-neutral substitute for fossil fuels. Through plant breeding, some willow clones produced over 25 tonnes dry matter $\mathrm{ha}^{-1} \mathrm{yr}^{-1}$ (CHRISTERSSON et al., 1993; VolK et al., 2006).

Breeding high-yield willow clones as a source for bioenergy has recently been identified as one of the key Sci-tech programs in Jilin province of northeast China. Although there are 37 native varieties of willow in Jilin, most of these do not respond well to intensive forest management, with low biomass production of only about 2-6 tonnes dry matter $\mathrm{ha}^{-1} \mathrm{yr}^{-1}$ (SHI, 2007). Thus, there is an urgency to develop high-productive willow clones. To meet this need quickly, introduction of high productivity, exotic willow clones may be the most inexpensive and effective method.

The province supported a program to import shrub willows with the aim of making them a reliable crop for energy production, and keeping an option open for other purposes such as for pulp. A successful introduction pro- gram for tree species typically involves two phases with the first being a short-term evaluation of adaptation and growth potential, followed by a second-phase involving large scale multiple-site testing to quantify yield. In 2002, 12 willow clones were introduced from New York, USA, and planted in Jilin in 2003 as the first-phase test. The objectives of this study were to provide an evaluation of the adaptation, growth potential, and wood quality traits in the receptor area, and then to make selections for the second-phase large-scale yield testing.

\section{Materials and Methods}

\section{Clonal test}

In 2002, unrooted dormant cuttings, $25 \mathrm{~cm}$ in length, of 12 clones representing various origins and willow species (Table 1) were imported from New York $\left(42^{\circ} 47^{\prime} \mathrm{N}, 6^{\circ} 07^{\prime} \mathrm{W}\right)$, USA. Two indigenous clones (ZA1 and ZA2), currently used in willow plantations in Jilin, were included for comparison. The test was established in 2003 on abandoned farm land at the Lushui River $\left(42^{\circ} 31^{\prime} \mathrm{N}, 127^{\circ} 47^{\prime} \mathrm{E}\right)$, Fusong County, Jilin province. The site was located at $750 \mathrm{~m}$ in elevation, with an annual average temperature of $2.7^{\circ} \mathrm{C}$, relative humidity of $70.2 \%$, and annual precipitation of $872 \mathrm{~mm}$. Site preparation, completed in early 2002 , included plowing, disking, and raking. The test was planted as a randomized block design of three blocks and 10 tree-row plots at a spacing of $70 \times 100 \mathrm{~cm}$. In October 2003, at the end of the first growing season, the shrubs were cut back (coppiced) at $2-4 \mathrm{~cm}$ above ground to promote coppice regrowth. Other than manual weed control, no other treatments were applied to the test.

\section{Sampling and measurement}

Adaptive traits: Bud phenology, survival, frost resistance, and leaf rust (Melampsora epitea) damage were

Table 1. - List of willow clones deployed in the first-phase test at Lushui River, Jilin.

\begin{tabular}{lll}
\hline Clone & Species & Origin \\
\hline 94005(FC189) & Salix purpurea & New York, USA \\
$94006(\mathrm{FC} 190)$ & Salix purpurea & New York, USA \\
94009 (B193) & Salix purpurea & New York, USA \\
S95042 & Salix purpurea & New York, USA \\
S25 & Salix eriocephala $($ S. erio $)$ & Ontario, Canada \\
S287 & Salix erio & Ontario, Canada \\
95018 & Salix erio $x$ S. erio & Ontario, Canada \\
S95316 & Salix erio x S. erio & Ontario, Canada \\
S625 & Salix erio $x$ S. interior & Ontario, Canada \\
SV1 & Salix dasyclados & Ontario, Canada \\
S365 & Salix discolor & Quebec, Canada \\
SA2 & Salix alba & Novi Sad, Yugoslavia \\
ZA1 & Salix babylonica x S. fragilis & Jilin, China \\
ZA2 & Salix umbraculifera & Jilin, China \\
\hline
\end{tabular}


investigated on each individual ramet. Tree phenology was recorded every 5 days between May $5^{\text {th }}$ and $20^{\text {th }}$, and every 10 days between July $30^{\text {th }}$ and September $20^{\text {th }}$ in 2005, and May 2006 using a discrete scale system of six stages: 1, swollen buds; 2 , buds opening, leaf tips clearly visible; 3, individual leaves expanding; 4, stem elongation initiated; 5, height growth stopped; and 6, leaf senescence started. Survival was recorded as either 1 (alive) or 0 (dead). Frost resistance was scored by considering the percent damage on the main stem, using a scale of 1 to $5 \quad(1=$ no; $2=<1 / 3 ; 3=1 / 3 ; 4=1 / 3$ to $1 / 2$; $5=>1 / 2$ ). A scale system of 1 (affected) and 0 (not affected) was used to score leaf rust damage. Scoring for frost resistance was done in May while for rust was in August 2006.

Growth traits: Height, diameter, number of stems, and number of main roots were investigated for individual ramets. Measurements of the diameter and height, which were made in mid-September, were taken on the main stem only. Stem diameter was taken at $30 \mathrm{~cm}$ from the point of emergence from the cutting in 2004 and 2005. Stem height was measured annually from the base of the stem to the terminal bud from 2004 to 2006 . In late April 2007, these ramets in block 1 were removed from the soil, and the number of stems per stool and number of main roots (formed from the cutting) were counted.

Wood-quality traits: Lignin and cellulose content were measured. Following the measurement of the number of stems and main roots, five ramets per clone were randomly selected. The sampled trees were cut at the base, bagged, and tagged by clone, and the complete green stem samples were oven-dried $8-10 \mathrm{~h}$ at $105^{\circ} \mathrm{C}$. The dried samples were pulverized, mixed, and sieved $(0.25 \mathrm{~mm})$ by clone. Three samples $(1.0 \mathrm{~g}$ per sample) per clone were randomly prepared for measurement. Measurement of crude fiber and cellulose were made following Van Soest's method (VAN SoEST and WinE, 1967).

\section{Data analyses}

All analyses were carried out using Statistical Analysis System (1990). Data for height, diameter, and frostresistance were analyzed following a model that included block, clone and their interaction using the PROC MIXED procedure. All factors except clone were treated as random. Since survival data are binomial, survival was analyzed following the same model, but using PROC GLIMMIX procedure with the logit link function. Data for number of stems, number of main roots, and wood-quality traits were analyzed using PROC GLM procedure based on a model including clone, which was treated as a fixed effect. The clone means were calculated using the Estimate statement and the comparison between each clone and the control (the average performance of the two local clones) was made using the Contrast statement. Note that here and elsewhere in the text, except where otherwise indicated, the term significant refers to $\mathrm{p}<0.05$.

Since many variables were involved, a cluster analysis (PROC CLUSTER) was used to group clones on a multivariate basis into growth and adaptive potential classes. Ward's minimum variance method was used to construct the classes (DUDA and HART, 1973). The analysis was performed using the values of the variables which showed significant variation among clones. Note that S365 was removed from all analyses as it was severely damaged by low temperature in 2005, and no leaf rust damage was observed, thus this data was not included in further analysis.

\section{Results}

Table 2 lists the summary statistics of the measured traits, together with the $F$-values from the analyses of variance. After one rotation, the imported clones were, on average, $2.9 \mathrm{~m}$ in height, had $94 \%$ survival, and developed 14 stems and 2.1 main roots per stool. The

Table 2. - Overall mean, range, coefficients of variation (CV), and the clone effect $F$-value and significance level.

\begin{tabular}{lllll}
\hline Trait (unit) & Mean & Range & CV (\%) & $F$-value \\
\hline Survival (\%) & 94.8 & $86.5-100$ & 11.6 & $0.81 \mathrm{~ns}$ \\
Frost resistance & 1.2 & $1.0-1.7$ & 34.9 & $5.47 * *$ \\
Height_yr1 (m) & 1.0 & $0.8-1.4$ & 33.7 & $16.24 * *$ \\
Height_yr2 (m) & 2.2 & $1.7-2.9$ & 28.0 & $45.27 * *$ \\
Height_yr3 (m) & 2.9 & $1.6-4.1$ & 28.3 & $99.51^{* *}$ \\
Diameter_yr1 (cm) & 1.7 & $1.3-2.2$ & 30.3 & $16.75^{* *}$ \\
Diameter_yr2 (cm) & 2.3 & $1.6-2.8$ & 30.4 & $15.50^{* *}$ \\
Stem number & 14.0 & $9.1-23.4$ & 42.7 & $7.97 * *$ \\
Main root number & 2.1 & $0.8-3.7$ & 54.8 & $14.69 * *$ \\
Lignin (\%) & 18.9 & $16.8-21.7$ & 8.5 & $3.53 *$ \\
Cellulose (\%) & 57.2 & $54.0-59.4$ & 4.4 & $3.53 * *$ \\
\hline
\end{tabular}

ns, non-significant; $* \mathrm{P}<0.05$; and $* * \mathrm{P}<0.01)$ of the analysis of variance for 11 traits measured on willow clones planted at Lushui River, Jilin. 
average diameter was $2.3 \mathrm{~cm}$ after 2 years growth. All imported clones except S365 resisted frost well with an average resistance of 1.2 . The average wood quality traits were $57.2 \%$ for cellulose and $18.9 \%$ for lignin. The phenotypic variation, as shown by the coefficient of variation, was highest for number of main roots and stems, followed by frost, height, diameter, and survival, while lignin and cellulose contents showed the smallest variation. As shown by the range and $F$-values, all the measured traits, except survival, were statistically significant among clones.

The imported clones exhibited good adaptation and showed parallel bud phenology to the controls (Figure 1). In 2005, all clones except clone S365 had shown swollen buds at May $5^{\text {th }}$, broken bud and showed visible leaf tips around May $10^{\text {th }}$, entered leaf expansion by May $15^{\text {th }}$, initiated shoot growth by May $20^{\text {th }}$, stopped height growth around August $20^{\text {th }}$, and started leaf

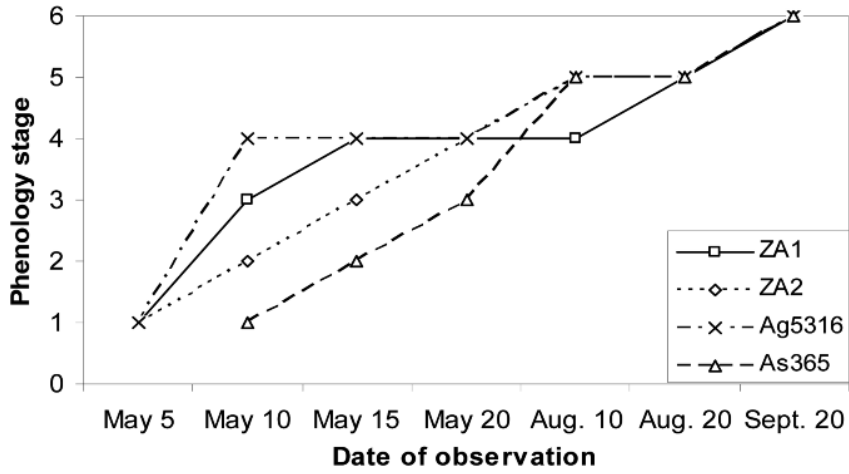

Figure 1. - Observed phenology stages at various dates in 2005 of shrub willow clones planted at Lushui River. The phenology stages were: 1 , swollen buds; 2 , bud opening, leaf tips clearly visible; 3 , individual leaves expanding; 4 , stem elongation initiated; 5 , height growth stopped; and 6 , leaf senescence started. Note that clones 95018, 94006, S95042, 94005, S625, S95316, 94009, S287, S25 and SA2 displayed the same development as ZA1 while clone SV1 was the same as ZA2. senescence Sept $20^{\text {th }}$. Because of colder weather in 2006 , bud development was delayed, i.e., reaching stage 1 around May $10^{\text {th }}$. Each clone survived well, all $>83 \%$. Relative to the controls, two clones (95042 and 95018) had a lower $(7.5 \%)$ survival while the others showed higher (ranging from 1.6 to $6.9 \%$ ) percentages (Table 3 ). Excellent frost resistance was found for the introduced clones. Clones 94005, 95042, 95018, 95316, and S625 were totally absent from frost damage whereas clones 94006, 94009, SV1, S287, and SA2 displayed negligible damage, with an average of less than 1.2. Thus, compared to the controls (1.4 and 1.1 for ZA1 and ZA2, respectively), the introduced clones were either comparable or better in frost resistance (Table 3). The exceptions were S365 and S25. S365 was killed by low temperature in late 2005 while S25 was significantly poorer in frost resistance than the control. Even for S25, frost damage was not substantial, with an average resistance value of only 1.7. No leaf rust damage was observed on all clones including the controls.

The imported clones grew well with some displaying better potential for biomass production than the controls (Table 3). Although most imported clones were statistically shorter and smaller than the control after one rotation, clone 95042 maintained its height superiority through these years. Five clones were statistically comparable to the controls in diameter. Most clones showed strong coppice ability, in particular 95042 and 94005 with each having 23.4 and 17.5 stems per stool, an increase of $67.1 \%$ and $25.0 \%$ over the control average, respectively. Exceptions were 94009 and 95316, which developed 8.2 and 9.1 stems per stool. Similarly, all the clones except 95316 and SA2 developed more main roots than the control. Clones 94009 and 94005 were especially good, with each having 3.4 and 3.7 main roots.

Most clones had a comparable amount of lignin to that of the control. Exceptions were clones 95018 and 94006, which had a significantly higher amount of lignin than

Table 3. - Relative values (\%) over the control and their significance.

\begin{tabular}{|c|c|c|c|c|c|c|c|c|c|c|c|}
\hline Clone & Survival & $\begin{array}{l}\text { Frost } \\
\text { l resistance }\end{array}$ & $\begin{array}{l}\text { Number of } \\
\text { stems }\end{array}$ & $\begin{array}{l}\text { Number of } \\
\text { main roots }\end{array}$ & $\begin{array}{l}1^{\text {st }} \text {-yr } \\
\text { Height }\end{array}$ & $\begin{array}{l}2^{\text {nd }}-y r \\
\text { Height }\end{array}$ & $\begin{array}{l}3 \text { rd-yr } \\
\text { Height }\end{array}$ & $\begin{array}{l}1^{\text {st }}-\mathrm{yr} \\
\text { Diameter }\end{array}$ & $\begin{array}{l}2^{\text {nd }}-\mathrm{yr} \\
\text { Diameter }\end{array}$ & Lignin & Cellulose \\
\hline 94005 & $1.6 \mathrm{~ns}$ & $-23.1 * *$ & $25.0^{*}$ & $221.7^{* *}$ & $8.3 \mathrm{~ns}$ & $-18.5^{* * *}$ & $-20.5 * *$ & $-33.3^{* *}$ & $-28.6^{* *}$ & $11.5 \mathrm{~ns}$ & $5.8 \mathrm{~ns}$ \\
\hline 94006 & $6.9 \mathrm{~ns}$ & $-7.7 \mathrm{~ns}$ & $-13.6 \mathrm{~ns}$ & $39.1 \mathrm{~ns}$ & $0.0 \mathrm{~ns}$ & $-7.4 * *$ & $-17.8 * *$ & $-28.2^{* *}$ & $-28.6^{* *}$ & $19.2 * *$ & $-0.4 n s$ \\
\hline 94009 & $4.3 \mathrm{~ns}$ & $-15.4^{*}$ & $-41.4^{* *}$ & $195.7^{* *}$ & $-8.3 \mathrm{~ns}$ & $-29.6^{* *}$ & $-34.2 * *$ & $-33.3^{* *}$ & $-42.8 * *$ & $1.6 \mathrm{~ns}$ & $4.6 \mathrm{~ns}$ \\
\hline 95042 & $-7.5 \mathrm{~ns}$ & $-23.1 * *$ & $67.1^{* *}$ & 73.9ns & $16.7^{* *}$ & $7.4 *$ & $12.3 * *$ & $-2.6 n s$ & $-3.6 n s$ & $-7.7 \mathrm{~ns}$ & $18.4 * *$ \\
\hline 95018 & $-7.5 \mathrm{~ns}$ & $-23.1^{* *}$ & $14.3 \mathrm{~ns}$ & $13.0 \mathrm{~ns}$ & $-33.3^{* *}$ & $-37.0^{* *}$ & $-45.2 * *$ & $-7.7 \mathrm{~ns}$ & $-21.4^{* *}$ & $10.4 *$ & $-0.9 \mathrm{~ns}$ \\
\hline 95316 & $6.9 \mathrm{~ns}$ & $-23.1^{* *}$ & $-35.0^{* *}$ & $-30.4^{* *}$ & $-33.3 * *$ & $-37.0^{* *}$ & $-37.0 * *$ & $-28.2^{* *}$ & $-28.6^{* *}$ & $-0.5 \mathrm{~ns}$ & $5.5 \mathrm{~ns}$ \\
\hline SV1 & $6.9 \mathrm{~ns}$ & $-15.4^{*}$ & $-0.7 \mathrm{~ns}$ & $108.7^{* *}$ & $0.0 \mathrm{~ns}$ & $-7.4 \mathrm{~ns}$ & $-26.0^{* *}$ & $12.8^{*}$ & $0.1 \mathrm{~ns}$ & $-4.4 \mathrm{~ns}$ & $5.3 \mathrm{~ns}$ \\
\hline S25 & $6.9 \mathrm{~ns}$ & $30.8^{* *}$ & $-9.3 n s$ & $126.1^{* *}$ & $16.7^{*}$ & $3.7 \mathrm{~ns}$ & $-17.8^{* *}$ & $7.7 \mathrm{~ns}$ & $-3.6 \mathrm{~ns}$ & $6.5 \mathrm{~ns}$ & $8.2 * *$ \\
\hline S287 & $4.3 \mathrm{~ns}$ & $-7.7 \mathrm{~ns}$ & $10.0 \mathrm{~ns}$ & $134.8^{* *}$ & $25.0^{* *}$ & $-25.9^{* *}$ & $-31.5^{* *}$ & $-2.6 n s$ & $-3.6 n s$ & $2.2 \mathrm{~ns}$ & $1.9 \mathrm{~ns}$ \\
\hline S625 & $4.3 \mathrm{~ns}$ & $-23.1 * *$ & $0.0 \mathrm{~ns}$ & $108.7^{* *}$ & $-16.7^{*}$ & $-14.8^{* * *}$ & $-23.3 * *$ & $-7.7 \mathrm{~ns}$ & $-7.1 \mathrm{~ns}$ & $-0.5 \mathrm{~ns}$ & $6.0^{*}$ \\
\hline $\mathrm{SA} 2$ & $1.6 \mathrm{~ns}$ & $-7.7 \mathrm{~ns}$ & $10.0 \mathrm{~ns}$ & $-4.3 n s$ & $-8.3 \mathrm{~ns}$ & $-18.5^{* *}$ & $-17.8 * *$ & $2.6 \mathrm{~ns}$ & $-10.7^{*}$ & $3.3 \mathrm{~ns}$ & $1.9 \mathrm{~ns}$ \\
\hline Control mean & $93.6 \%$ & 1.3 & 14 & 1.2 & $1.2 \mathrm{~m}$ & $2.7 \mathrm{~m}$ & $3.7 \mathrm{~m}$ & $2.0 \mathrm{~cm}$ & $2.8 \mathrm{~cm}$ & $18.2 \%$ & $54.4 \%$ \\
\hline
\end{tabular}

ns, non-significant at $\mathrm{P}<0.05$; *significant at $\mathrm{P}<0.05$; and ** significant at $\mathrm{P}<0.01$ ) over the control (average on the bottom line) for traits measured in the trial at Lushui River, Jilin. 


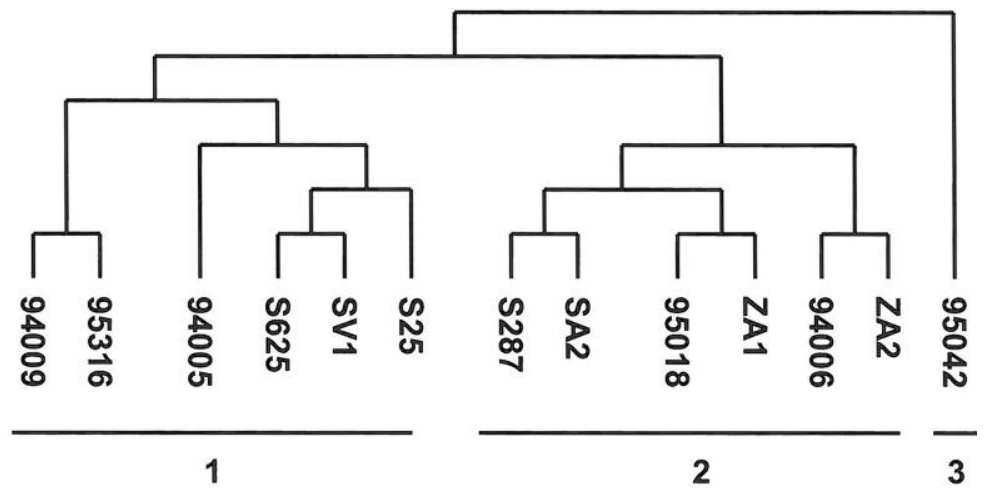

Cluster 1

3

Figure 2. - Cluster analysis dendrogram for 10 traits with significant clone effect observed in the trial planted at Lushui River, Jilin.

the control. For cellulose, the clones showed either a comparable or higher amount than the control with some (clones 95042, S25 and S625) reaching the significant level.

Cluster analysis revealed three distinct classes (Figure 2). These clusters were significantly different based on the pairwise comparison of the distances among the centroids $(\mathrm{P}<0.01)$. Cluster 1 contained clones having relatively good frost resistance, growth potential, and high cellulose while cluster 2 contained those having a small number of roots and relatively poor frost resistance. The third cluster only included one clone, 95042, which is good in all the traits. Some exceptions occurred; for example, 95316 had the smallest number of stems and main roots, but was grouped to the $1^{\text {st }}$ cluster.

\section{Discussion}

For a successful tree introduction program, good adaptation, in particular, resistance to biotic and abiotic stresses due to new environmental conditions is essential. In this regard, results of this study were very promising; after one rotation, the imported clones consistently maintained high survival, displayed adequate resistance to frost and leaf rust, and showed similar phenology to the controls. Good adaptation of the imported clones to the receptor environment was not unexpected. First, the similar climate between Jilin, New York, and Ontario was conducive for their adaptation. Second, these clones were the winners in prior genetic selection trials in terms of survival, yield, and low incidence of disease and pest problems (MOSSELER et al., 1988). The high survival and strong frost resistance observed in the present study may simply be the consequences of prior genetic selection (THARAKAN et al., 2005). The only exception was S365, which appeared to not be well adapted to the receptor conditions. The poor adaptation of S365 was not surprising; as even when planted in Quebec, Canada, its place of origin, severe symptoms of frost damage on stems were frequently noted (LABRECQUE and TEODORESCU, 2003).

In addition to good adaptation, good growth (biomass) potential should be another criterion. High biomass production includes many components of growth such as size of stems, number of stems and roots (MOSSELER et al., 1988; Kuzovkina and VolK, 2009). Compared to the controls, some imported clones grew at a similar rate in main stem (i.e., 95042) or showed a stronger ability to develop stems and main roots (i.e., 95042, 94005 and 94009), suggesting a good potential for higher biomass production. Surprisingly, the stem numbers for some clones (i.e., SV1 and S625) observed in this study were higher than those when they were planted in Tully, New York (TharakAN et al., 2001, 2005). Parallel to stem number, strong ability to develop main roots quickly has positive effects on biomass productivity. First, more main roots provide more areas for coppicing. Second, the quick establishment of the root system will allow the tree to allocate more carbohydrates to aboveground growth in the subsequent rotations, resulting in higher yield in later rotation.

Other than good adaptation and growth, results of wood quality traits for pulping were also encouraging. Since only cellulose fiber is needed and most water soluble and volatile lignin compounds need to be removed during pulping, low lignin and high cellulose content is always ideal. Although most imported clones did not show superiority in reducing lignin content, their advantage over the controls in increasing cellulose was obvious. Selection of the top two clones (95042 and S25) resulted in an increase of $13 \%$ in cellulose over the controls. Even for lignin content, some improvement can be made via clonal selection, i.e, selection of 95042 and SV1 resulted in a $6 \%$ decrease.

Based on results of the multivariate approach, we recommended six clones (95042, SV1, S25, S625, 94009, and 94005) for the upcoming second-phase clone-site trials. These clones were characterized by a relatively large number of stems and main roots, high frost resistance and cellulose content. Most of these clones are plastic in nature, grow well across a range of sites and were ranked as the top biomass-producing clones in ongoing regional trials across the northeastern United States (KoPP et al., 2001a; THARAKAN et al., 2005).

The results reported here may be associated with some uncertainties. This study was based only on one site and lasted for one rotation of 3 years. Typically, a 
willow plantation, established as a short-rotation woody crop system, will last for about 25 years. However, an early and comprehensive estimation of clonal biomass production potential for willow clones has been demonstrated to be effective (THARAKAN et al., 2001; LABRECQUE and TEODORESCU, 2003). Furthermore, tree adaptation and growth depend on key climate variables, which vary with site. Low temperature is the key factor for successful establishment of willow. Once the crop is established, precipitation and growing degree days become the most limiting factors for willows (KoPP et al., 2001b). Lushui River is located within the coldest region in Jilin and has relative low growing degree days $(1,527$ with baseline $5{ }^{\circ} \mathrm{C}$ ). Thus, the high survival reported here may be maintained and their biomass production may be higher when planted in other regions across Jilin. Limited site and time period may have a substantial effect on the result of leaf rust damage. Leaf rust damage on native willows was rarely observed in the Lushui River area, but has been reported in other regions in Jilin (PEI et al., 2005). Furthermore, diseases have the ability to co-evolve with plants; thus potentially pathogenic organisms like leaf rust may go unnoticed for longer periods in a willow stand (VERWIJST, 2001). Thus, in the upcoming second-phase trials, the main edapticlimatic regions for deployment should be covered, and the trials should be maintained and monitored for a long period not only for yield, but also for disease resistance.

\section{Acknowledgement}

Many thanks go to Dr. Alex Mosseler for his valuable comments and suggestions on an earlier version of the paper. Thanks also go to two reviewers for their valuable suggestions and to Dale Simpson for his English editing. The research was supported by the "948" Program of State Forestry Administration of the P. R. China (grant No. 2002-5217) and by the Science and Technology Department of Jilin Province, P. R. China (grant No.20090715).

\section{Reference cited}

Christersson, L., L. Sennerby-Forsse and L. Zsuffa (1993): The role and significance of woody biomass plantations in Swedish agriculture. The Forestry Chronicle 69: 687-693.

DudA, R. O. and P. E. HART (1973): Pattern classification and scene analysis. New York: John Wiley \& Sons, Inc. 482pp.
Kopp, R. F., L. P. Abrahamson, E. H. White, T. A. Volk, C. A. NowaK and R. C. Fillhart (2001a): Willow biomass production during ten successive annual harvests. Biomass and Bioenergy 20: 1-7.

Kopp, R. F., L. B. SMart, C. A. Maynard, J. G. Isebrands, G. A. Tuskan and L. P. Abrahamson (2001b): The development of improved willow clones for eastern North America. The Forestry Chronicle 77: 287-292.

KuZovkinA, Y. and T. A. VolK (2009): The characterization of willow (Salix L.) varieties for use in ecological engineering applications: Co-ordination of structure, function and autecology. Ecological Engineering 35: 1178-1189.

LABRECQUe, M. and T. I. Teodorescu (2003): High biomass yield achieved by Salix clones in SRIC following two 3-year coppice rotations on abandoned farmland in southern Quebec, Canada. Biomass and Bioenergy 25: 135-146.

Mosseler, A., L. Zsuffa, M. U. Stoehr and W. A. Kenney (1988): Variation in biomass production, moisture content, and specific gravity in some North American willows (Salix L.). Canadian Journal of Forest Research 18: $1535-1540$.

Pei, M. H., C. BAYON and C. Ruiz (2005): Phylogenetic relationships in some Melampsora rusts on Salicaceae assessed using rDNA sequence information. Mycological Research 109: 401-409.

SHI, S. Z. (2007): Willow as a source for bioenergy - discussion (In Chinese). Jiangsu Forest Science and Technology 34: 46-54.

StATISTICAL ANALYSIS SYSTEM (1990): SAS procedure guides. Version $6,3^{\text {rd }}$ edn. SAS Institute Inc., Cary, NC.

Tharakan, P. J., D. J. Robison, L. P. Abrahamson and C. A. NowAK (2001): Multivariate approach for integrated evaluation of clonal biomass production potential. Biomass and Bioenergy 21: 237-247.

Tharakan, P. J., T. A. Volk, C. A. NowaK and L. P. AbraHAMSON (2005): Morphological traits of 30 willow clones and their relationship to biomass product. Canadian Journal of Forest Research 35: 421-431.

VAN Soest, P. J. and R. H. Wine (1967): Use of detergents in the analysis of fibrous feeds. Preparation of fibre residues of low nitrogen content. Determination of cellwall constituents. J. Assoc. Off. Anal Chem 50: 50-55.

VERWIJST, T. (2001): Willows: An underestimated resource for environment and society. The Forestry Chronicle 77: 281-285.

Volk, T. A., L. P. Abrahamson, C. A. Nowak, L. B. Smart, P. J. Tharakan and E. H. White (2006): The development of short-rotation willow in the northeastern United States for bioenergy and bioproducts, agroforestry and phytotemediation. Biomass and Bioenergy 30: 715-727. 